\title{
PENGARUH HARGA, PROMOSI, LAYANAN PURNA JUAL, TERHADAP KEPUTUSAN KONSUMEN MEMBELI MOTOR METIC PADA PT GIOVANI PALU
}

\author{
Albar Alaydrus ${ }^{1}$, Labandingi Latoki ${ }^{1}$ dan Veronika ${ }^{2}$ \\ ${ }^{1}$ Dosen Fakultas Ekonomi Universitas Alkhairaat \\ ${ }^{2}$ Mahasiswa Fakultas Ekonomi Universitas Alkhairaat
}

\begin{abstract}
ABSTRAK
Adapun tujuan penelitian ini untuk menguji dan menganalisis Pengaruh Harga, Promosi, Layanan Purna Jual, Terhadap Keputusan Konsumen Membeli Motor Metic pada PT Giovani Palu. Penelitian ini merupakan uraian atau penjelasan dari hasil pengumpulan data primer berupa koesioner yang telah di isi oleh responden penelitian. Dalam penelitian ini, penentuan jumlah sampel menggunakan pendekatan Tabachic \& Fidell (2002). besarnya sampel ditentukan sebanyak 25 kali variabel Independen jadi jumlah sampel yang digunakan adalah 75. Berdasarkan hasil pengujian Multiple atau koefisien korelasi (R) adalah hubungan antara ketiga variabel bebas yaitu harga, promosi, layanan purna jual, terhadap keputusan konsumen membeli sebesar 0,862 atau 86,2\% artinya hubungan variabel bebas (independen) terhadap variabel terikat (dependen) adalah sangat kuat. $\mathrm{R}$ Square atau koefisien determinasi $\left(\mathrm{R}^{2}\right)$ adalah melihat pengaruh antara variabel harga, promosi, layanan purna jual, terhadap keputusan konsumen membeli sebesar $74,3 \%$ artinya pengaruh variabel bebas (independen) terhadap variabel terikat (dependen). Sedangkan sisanya $25,7 \%$ adalah pengaruh variabel lain yang tidak diteliti dalam penelitian ini.
\end{abstract}

Kata Kunci: Harga, Promosi, Layanan Purna Jual, dan Keputusan.

\section{LATAR BELAKANG}

Perilaku konsumen memberikan informasi mengenai berbagai fakta tentang perilaku berbelanja (Setiadi, 2003; 8), misalnya dalam membeli suatu produk para konsumen memiliki berbagai sikap yang berbeda-beda dalam memandang berbagai atribut yang dianggap relevan dan penting (Kotler, 2005; 226). Mereka akan memberikan perhatian lebih besar pada atribut yang memberikan manfaat yang dicarinya. Atribut-atribut ini kemudian akan berperan dalam evaluasi keputusan pembelian. Proses pengambilan keputusan dibagi kedalam tiga jenis yaitu pengambilan keputusan yang luas, pengambilan keputusan yang terbatas, dan pengambilan keputusan yang bersifat kebiasaan. Proses pengambilan keputusan yang luas terjadi untuk kepentingan khusus bagi konsumen atau untuk pengambilan keputusan yang membutuhkan tingkat keterlibatan yang tinggi, misalnya pembelian produk-produk mahal, mengandung nilai prestis, dan dipergunakan untuk waktu yang lama (Fandi Tjiptono, 2001;21), salah satunya adalah keputusan pembelian motor. Industri sepeda motor merupakan industri yang sedang tumbuh pesat di Indonesia belakangan ini. Besarnya minat masyarakat Indonesia untuk memiliki kendaraan roda dua dipengaruhi banyak faktor. Menurut Ketua AISI, Ridwan Gunawan, semua itu dipicu oleh kebutuhan akan alat transportasi pribadi yang cukup tinggi. Ini sebagai dampak masih belum memadainya sarana transportasi umum di Indonesia. Selain itu, sepeda motor adalah kendaraan yang sesuai dengan karakteristik masyarakat. Dilihat dari harganya, sepeda motor jauh lebih murah dan terjangkau masyarakat Indonesia dibandingkan kendaraan roda empat, harganya relatif tidak beranjak naik. Komponen sepeda motor yang lebih dari $90 \%$ dibuat lokal, membuatnya sangat fleksibel terhadap perubahan harga. Kenaikan harga minyak bumi juga tidak mempengaruhi penjualan motor karena membuat masyarakat mencari sarana transportasi yang berharga terjangkau dan 
efisien bahan bakar (Media Motor, 2008). Kondisi ini ditunjang dengan cara kepemilikan sepeda motor yang semakin mudah.

Dengan uang muka di bawah Rp 1.000.000, masyarakat sudah bisa memiliki sepeda motor. Kemudian cicilan yang bisa diangsur sampai 48 bulan membuat kepemilikan sepeda motor semakin tinggi di Indonesia. Dari berbagai macam produk yang dikeluarkan, Yamaha matic merupakan produk andalan Yamaha Motor. Seperti yang kita ketahui Yamaha adalah Trendsetter motor masa depan. Yamaha adalah produsen motor pertama di indonesia yang meluncurkan motor matic yaitu diluncurkannya motor matic pertamanya adalah Yamaha Nouvo pada tahun 2004, kemudian disusul oleh Yamaha Mio yang diluncurkan 1 tahun berikutnya yaitu tahun 2005 yang langsung disambut baik oleh masyarakat luas. Karena dominannya penjualan Yamaha Matic maka penelitian ini memfokuskan pada keputusan pembelian Yamaha Matic.

Adapun cara promosi dan pelayanan yang diberikan ole PT.GIOVANI PALU sangatlah menarik dibandingkan dengan diler motor lain pada umumnya.yaitu salah satunya bekerjasama dengan beberapa club motor matic khusus yamaha di Kota Palu. Dengan mengadakan nonton bareng motor GP di depan diler GIOVANI, atau mengadakan rolling bersama bikers Kota Palu adalah salah satu contoh pendekatan kepada konsumenya, dan dengan cara tersebut juga secara tidak langsung adalah bentuk promosi mengenai pelayanan, diler GIOVANI juga punya cara yang unik, seperti mengucapkan happy bday kepada konsumennya juga melakukan komunikasi dengan konsumennya saat konsumen melakukan servis berkala, dengan demikian PT.GIOVANI PALU dapat dijadikan salah satu diler pilihan yang terpercaya, nyaman, dan bisa memenuhi kebutuhan pecinta motor matic di Kota Palu.

Berdasarkan latar belakang di atas, penelitian ini akan menganalisis faktor-faktor yang mempengaruhi keputusan pembelian konsumen terutama keputusan pembelian motor Yamaha Matic pada PT Giovani Palu. Berdasarkan latar belakang tersebut, maka penulis tertarik melakukan penelitian pada PT Giovani Palu dengan Judul: "Pengaruh Harga, Promosi, Layanan Purna Jual, Terhadap Keputusan Konsumen Membeli Motor Metic pada PT Giovani Palu".

\section{Rumusan Masalah}

Berdasarkan latar belakang yang di atas dikemukakan sebelumnya, maka perumusan masalah dalam penelitian ini adalah sebagai berikut:

1. Apakah Harga, Promosi, Layanan Purna Jual, secara serempak berpengaruh signifikan terhadap Keputusan Konsumen Membeli Motor Metic pada PT Giovani Palu?

2. Apakah Harga secara parsial berpengaruh signifikan terhadap Keputusan Konsumen Membeli Motor Metic pada PT Giovani Palu?

3. Apakah Promosi secara parsial berpengaruh signifikan terhadap Keputusan Konsumen Membeli Motor Metic pada PT Giovani Palu?

4. Apakah faktor Layanan Purna Jual secara parsial berpengaruh terhadap Keputusan Konsumen Membeli Motor Metic pada PT Giovani Palu?

\section{KAJIAN PUSTAKA \\ Harga}

Harga yang merupakan satu-satunya unsur bauran pemasaran yang seringkali dijadikan sebagai bahan pertimbangan bagi konsumen dalam melakukan pembelian tidak bisa dikesampingkan oleh perusahaan. Swastha (2001) mendefinisikan harga sebagai sejumlah uang (ditambah beberapa produk) yang dibutuhkan untuk mendapatkan sejumlah kombinasi dari produk dan pelayanannya. Dari definisi diatas dapat diketahui bahwa harga yang dibayar oleh pembeli sudah termasuk layanan yang diberikan oleh penjual. Banyak perusahaan mengadakan pendekatan terhadap penentuan harga berdasarkan tujuan yang hendak dicapainya. Adapun tujuan tersebut dapat berupa meningkatkan penjualan, mempertahankan market share, mempertahankan stabilitas harga, mencapai laba maksimum dan sebagainya.

Harga menurut Kotler dan Amstrong (2001) adalah sejumlah uang yang ditukarkan untuk sebuah produk atau jasa. Lebih jauh lagi, harga adalah jumlah dari seluruh nilai yang konsumen tukarkan untuk jumlah manfaat dengan memiliki atau menggunakan suatu barang dan jasa. Harga merupakan faktor penentu yang mempengaruhi pilihan pembelian, hal ini masih menjadi kenyataan di negara-negara dunia ketiga, di kalangan kelompok-kelompok sosial yang miskin, serta pada bahan-bahan pokok sehari-hari. Namun dalam dasawarsa terakhir ini, faktor-faktor lain selain harga telah beralih menjadi relatif lebih penting dalam proses pembelian. 
Harga dapat menunjukkan kualitas merek dari suatu produk, dimana konsumen mempunyai anggapan bahwa harga yang mahal biasanya mempunyai kualitas yang baik. Pada umumnya harga mempunyai pengaruh yang positif dengan kualitas, semakin tinggi harga maka semakin tinggi kualitas. Konsumen mempunyai anggapan adanya hubungan yang positif antara harga dan kualitas suatu produk, maka mereka akan membandingkan antara produk yang satu dengan produk yang lainnya, dan barulah konsumen mengambil keputusan untuk membeli suatu produk.

\section{Promosi}

Promosi merupakan teknik komunikasi yang secara penggunaannya atau penyampaiannya dengan menggunakan media seperti: pers, televisi, radio, papan nama, poster dan lain-lain, yang tujuannya untuk menarik minat konsumen terhadap hasil produksi suatu perusahaan. Promosi sebagai media untuk menjembatani kepentingan produsen dengan konsumen harus benar-benar dipahami oleh seorang manajer.

Menurut Swastha (2006) mengatakan bahwa: "Promosi adalah arus informasi atau persuasi satu arah yang dibuat untuk mengarahkan seseorang atau organisasi kepada tindakan yang menciptakan pertukaran dalam pemasaran”.

Definisi menurut Swastha (2007): "Promosi adalah komunikasi non individu dengan sejumlah biaya, melalui berbagai media yang dilakukan oleh perusahaan, lembaga-lembaga non laba serta individu-individu". Menurut Tjiptono (2002) promosi adalah: "Aktivitas pemasaran yang berusaha menyebarkan informasi, mempengaruhi atau membujuk dan mengingatkan pasar sasaran atas perusahaan dan produknya agar bersedia menerima, membeli, dan loyal pada produk yang ditawarkan perusahaan yang bersangkutan". Dari uraian definisi promosi menurut beberapa ahli di atas maka dapat disimpulkan bahwa promosi adalah kegiatan yang dilakukan oleh perusahaan dengan jalan mempengaruhi konsumen secara langsung ataupun tidak langsung untuk meningkatkan omzet penjualan melalui penciptaan pertukaran dalam pemasaran barang.

Menurut Kotler dan Armstrong (2001) variabel-variabel yang ada di dalam promotional mix ada lima, yaitu:

1. Periklanan (adveritising)

Segala biaya yang harus dikeluarkan sponsor untuk melakukan presetasi dan promosi non pribadi dalam bentuk gagasan, barang atau jasa.

2. Penjualan Personal (personal selling)

Presentasi pribadi oleh para wiraniaga perusahaan dalam rangka mensukseskan penjualan dan membangun hubungan dengan pelanggan.

3. Promosi penjualan (sales promotion)

Insentif jangka pendek untuk mendorong pembelian atau penjualan suatu produk atau jasa.

4. Hubungan masyarakat (public relation)

Membangun hubungan baik dengan publik terkait untuk memperoleh dukungan, membangun "citra perusahaan" yang baik dan menangani atau menyingkirkan gosip, cerita dan peristiwa yang dapat merugikan.

5. Pemasaran langsung (direct marketing)

Komunikasi langsung dengan pelanggan yang diincar secara khusus untuk memperoleh tanggapan langsung.

Dengan demikian untuk menciptakan kegiatan pemasaran maka perusahaan harus dapat mengkombinasikan berbagai variabel yang ada agar menarik konsumen untuk melakukan keputusan pembelian.

Layanan Purna Jual

Sudarsono dan Edilius (2000) mendefinisikan layanan purna jual atau after sale service sebagai jasa pelayanan yang meliputi perbaikan, penyediaan suku cadang, dan lain-lain yang diberikan oleh perusahaan kepada konsumen setelah produknya dibeli untuk jangka waktu tertentu. Pemberian pelayanan purna jual biasanya dilakukan sebagai suatu bentuk tanggung jawab yang diberikan oleh penjual atas barang yang telah mereka jual. Pelayanan ini diberikan dalam bentuk pemberian garansi, penggantian barang-barang rusak, pemeliharaan dan penyediaan suku cadang (Barata, 2003).

Menurut Tjiptono (2000) terdapat beberapa alternatif strategi yang dapat dilakukan perusahaan untuk mengurangi kemungkinan terjadinya ketidakpastian adalah dengan penyediaan pelayanan purna jual yaitu pemberian garansi untuk mengurangi persepsi konsumen terhadap risiko pembelian, jasa reparasi, dan penyediaan suku cadang pengganti.

Menurut Kotler (2005) sebuah perusahaan harus menentukan bagaimana menawarkan jasa setelah penjualan (misalnya, jasa pemeliharaan dan perbaikan serta jasa pelatihan kepada pelanggan). 
Pada dasarnya penjualan atas dasar kedekatan dengan pelanggan dapat menciptakan loyalitas pelanggan atas produk tersebut. Selain itu pemasar juga dapat memperoleh pelanggan baru dari pelayanan yang mereka lakukan. Menurut (Marjun, 2019) Dimensi Kualitas Layanan harus diberikan secara konstan sehingga konsumen akan tetap puas atau bahkan sangat puas.

Berdasarkan beberapa pengertian tersebut dapat diambil kesimpulan bahwa pelayanan purna jual adalah suatu pelayanan yang diberikan oleh perusahaan kepada konsumen setelah pembelian untuk mengurangi ketidakpuasan dengan jalan memberikan garansi, jasa reparasi dan penyediaan suku cadang.

\section{Keputusan Pembelian}

Menurut (Badjamal, 2019) Keputusan pembelian merupakan sebuah tindakan yang dilakukan konsumen untuk membeli suatu produk. Dalam mengenal konsumen perlu mempelajari perilaku konsumen sebagai perwujudan dari seluruh aktivitas jiwa manusia dalam kehidupan sehari-hari. Persepsi-persepsi pengaruh orang lain dan motif-motif internal akan berinteraksi untuk menentukan keputusan terakhir yang dianggap paling sesuai. Perilaku konsumen adalah tindakantindakan yang dilakukan individu, kelompok atau organisasi yang berhubungan dengan proses pengambilan keputusan dalam mendapatkan, menggunakan barang-barang atau jasa ekonomis yang dapat dipengaruhi oleh lingkungan (Swastha, 2003).

Perilaku konsumen akan menentukkan proses pengambilan keputusan dalam pembelian mereka, proses tersebut merupakan sebuah pendekatan penyesuaian masalah yang terdiri dari lima tahap yang dilakukan konsumen, kelima tahap tersebut adalah pengenalan masalah, pencarian informasi, penilaian alternatif, membuat keputusan, dan perilaku pasca pembelian (Kotler, 2004).

Menurut Kotler (2004) kelima tahap yang dilalui konsumen dalam proses pengambilan keputusan pembelian dapat dirumuskan sebagai berikut:

1. Pengenalan Masalah

Proses pembelian dimulai dengan pengenalan masalah atau kebutuhan. Jika kebutuhan diketahui maka konsumen akan serta memahami kebutuhan yang belum perlu segera dipenuhi atau masalah dapat ditunda pemenuhannya, serta kebutuhan yang sama- sama harus segera dipenuhi. Jadi pada tahap inilah proses pembelian itu mulai dilakukan.

2. Pencarian Informasi

Seorang konsumen yang telah mengetahui kebutuhannya dapat atau tidak dapat mencari informasi lebih lanjut jika dorongan keinginan kuat, jika tidak kuat maka kebutuhan konsumen itu hanya akan menjadi ingatan belaka. Konsumen mungkin melakukan pencarian lebih banyak atau segera aktif mencari informasi yang mendasari kebutuhan.

3. Penilaian Alternatif

Setelah melakukan pencarian informasi sebanyak mungkin, konsumen menggunakan informasi untuk mengevaluasi beberapa merek alternatif dalam satu susunan pilihan.

4. Keputusan Pembelian

Jika keputusan yang diambil adalah membeli, maka pembeli akan menjumpai serangkaian keputusan yang menyangkut jenis pembelian, waktu pembelian, dan cara pembelian. Pada tahap ini konsumen benar-benar membeli produk.

5. Perilaku Setelah Membeli

Setelah membeli suatu produk, konsumen akan mengalami beberapa tingkatan kepuasan atau ketidakpuasan yang dirasakan, ada kemungkinan bahwa pembeli memiliki ketidakpuasan setelah melakukan pembelian karena tidak sesuai dengan keinginan atau gambaran sebelumnya, dan lain sebagainya.

\section{METODE PENELITIAN \\ Populasi}

Populasi adalah gabungan dari seluruh elemen yang berbentuk peristiwa, hal atau orang yang memiliki karakteristik yang serupa yang menjadi pusat perhatian seorang peneliti, karena itu dipandang sebagai sebuah semesta penelitian (Ferdinand, 2006). Menurut Sugiyono (2004) yang dimaksud dengan populasi adalah wilayah generalisasi yang terdiri atas subyek atau obyek yang mempunyai kualitas dan karakteristik tertentu yang ditetapkan oleh peneliti untuk dipelajari dan ditarik kesimpulannya. Populasi dalam penelitian ini adalah konsumen PT Giovani Palu.

\section{Sampel}

Sampel adalah subset dari populasi, terdiri dari beberapa anggota populasi (Ferdinand, 2006). Sampel merupakan bagian dari jumlah dan karakteristik populasi tersebut. Besarnya sampel 
sangat dipengaruhi oleh banyak faktor antara lain tujuan penelitian. Jika penelitian bersifat deskriptif, maka umumnya membutuhkan sampel yang besar, tetapi jika penelitiannya hanya menguji hipotesis dibutuhkan sampel dalam jumlah yang lebih sedikit (Ferdinand 2006).

Dalam penelitian ini, penentuan jumlah sampel menggunakan pendekatan Tabachic \& Fidell (Azis, 2019). Dalam penelitian Multivariate (termasuk yang menggunakan analisis regresi Multivariate) besarnya sampel ditentukan sebanyak 25 kali variabel Independen (Ferdinand, 2006). Jumlah variabel independen dalam penelitian ini adalah 3, sehingga jumlah sampel yang digunakan adalah 75 .

\section{Uji Asumsi Klasik}

Sebelum melakukan analisis regresi, agar perkiraan menjadi tidak bias, maka dilakukan beberapa uji asumsi klasik yang harus dipenuhi:

\section{a. Uji Normalitas}

Tujuan uji normalitas adalah untuk mengetahui apakah distribusi sebuah data mengikuti atau mendekati distribusi normal. Uji normalitas bertujuan untuk menguji apakah model regresi berdistribusi normal. Uji normalitas dapat dilakukan dengan analisis grafik dilihat dari titiktitik yang menyebar disekitar garis diagonal yakni distribusi data dengan bentuk lonceng dan distribusi data tersebut tidak menceng ke kiri atau menceng ke kanan. Uji normalitas dilakukan dengan mengunakan pendekatan kolmogorv sminorv. Dengan mengunakan tingkat signifikan $5 \%(0,05)$ maka jika nilai Asymp.Sig. (2-tailed) diatas nilai signifikan $5 \%$ artinya variabel residual berdistribusi normal.

\section{Gambar 1}

Normal P-P Plot of Regression Standardized Residual

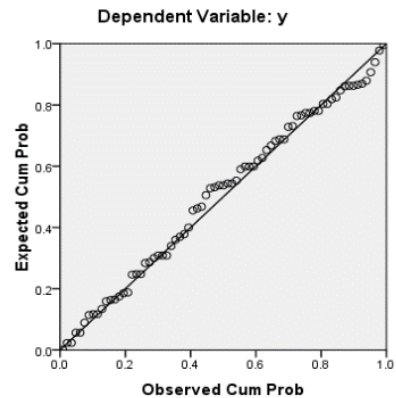

Gambar 1: pengujian normalitas P-P Plot Sumber: Hasil olahan SPSS 18,0 for windows

\section{b. Uji Heteroskedastisitas}

Model regresi yang baik adalah yang tidak terjadi Heteroskedastisitas. Untuk menguji Heteroskedastisitas dilakukan dengan analisis grafik. Melaui analisis grafik suatu model regresi diangap tidak terjadi Heteroskedastisitas jika titiktitik menyebar secara acak dan tidak membentuk suatu pola tertentu yang jelas serta tersebar diatas maupun dibawah angka nol pada sumbu $\mathrm{Y}$.

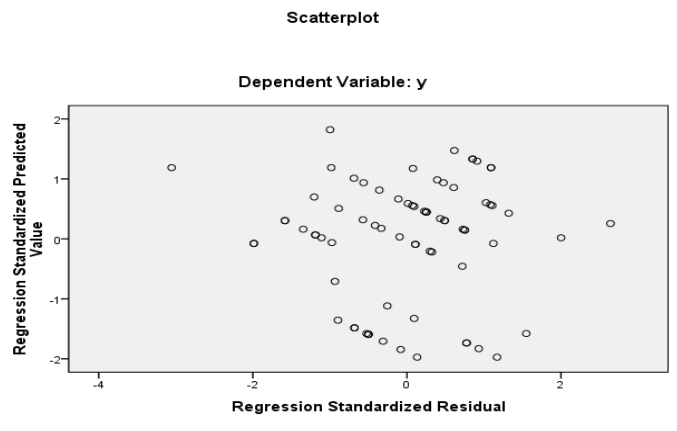

Gambar 2: pengujian Heteroskedastisitas scatterplot.

Sumber: hasil olahan SPSS 18,0 for windows

Gambar 2 memperlihatkan titik-titik menyebar secara acak dan tidak suatu pola tertentu yang jelas serta baik di atas maupun di bawah angka nol pada sumbu Y. Hal ini berarti tidak terjadi Heteroskedastisitas pada model regresi, sehingga model regresi layak dipakai untuk memprediksi keputusan konsumen membeli berdasarkan masukkan variabel independennya.

\section{c. Uji Multikolinearitas}

Multikolinearitas berarti adanya hubungan linier yang sempurna atau pasti di antara beberapa atau semua variabel yang menjelaskan dari model regresi. Untuk mendeteksi ada atau tidaknya Multikolinearitas dapat diketahui dengan melihat toleransi variabel dan variance inflation factor (VIF) dengan membandingkan sebagai berikut:

a) $\mathrm{VIF}<5$ maka tidak terdapat multikolinearitas

b) Tolerance $>$ maka tidak terdapat multikolinearitas

Tabel 1

Uji Multikolinieritas

\begin{tabular}{|c|c|c|c|}
\hline \multirow{2}{*}{ No } & Variabel & \multicolumn{2}{c|}{$\begin{array}{c}\text { Collinearity } \\
\text { Statistik }\end{array}$} \\
\cline { 3 - 4 } & & Tolerance & VIF \\
\hline 1 & Harga & .445 & 2.246 \\
\hline 2 & Promosi & .399 & 2.504 \\
\hline 3 & Layanan purna jual & .376 & 2.658 \\
\hline
\end{tabular}

Sumber: Hasil olahan SPSS 18 for windows data sudah diolah

\section{HASIL DAN PEMBAHASAN}




\section{Hasil Pengujian Regresi}

Analisis regresi linear berganda dalam penelitian ini digunakan untuk mengetahui pengaruh faktor harga (X1), Promosi (X2), layanan purna jual (X3), terhadap keputusan konsumen membeli pada PT Giovani Palu berdasarkan pengujian doperoleh hasil sebagai berikut:

Tabel 2

Hasil Pengujian Regresi Linear Berganda Faktor Terikat $=$ Keputusan Konsumen Membeli (Y)

\begin{tabular}{|l|r|r|r|}
\hline \multicolumn{1}{|c|}{ Variabel } & \multicolumn{1}{|c|}{$\begin{array}{c}\text { Standardized } \\
\text { Coefficients } \\
\text { (Beta) }\end{array}$} & \multicolumn{1}{c|}{$\begin{array}{c}\text { Std. } \\
\text { Error }\end{array}$} & Sig.t \\
\hline (Constant) & .401 & 1.514 & .792 \\
Harga & .404 & .098 & .000 \\
Promosi & .381 & .104 & .000 \\
Layanan Purna & .229 & .095 & .018 \\
Jual & & & \\
\hline
\end{tabular}

$\mathrm{n}=75$

Konstanta $=0,401$

Koefesien Korelasi $(\mathrm{R})=0,862$

Koefisien Determinasi $\left(R^{2}\right)=0,743$

F-Statistik $=68.308$

Sig.F $=0,000$

Sumber: Lampiran

Dari hasil pengujian dengan menggunakan regresi linier berganda di atas, maka dapat disusun persamaan regresi berganda dari pengaruh harga, promosi, layanan purna jual, terhadap keputusan konsumen membeli pada PT.Giovani Palu yaitu: $\mathrm{Y}=0,401+0,404 \mathrm{X} 1+0,381 \mathrm{X} 2+0,229 \mathrm{X3}+\mathrm{e}$

Hasil pengujian di atas menunjukan, di mana nilai konstanta 0,401 merupakan bilangan tepat yang berarti terjadi pengaruh harga (X1), promosi (X2), layanan purna jual (X3) terhadap terhadap keputusan konsumen membeli motor metik pada PT Giovani Palu yaitu 0,401.

Selanjutnya koefisien regresi faktor harga (X1) sebesar 0,404 memberikan arti bahwa jika terjadi perubahan X1 sebesar satu satuan maka keputusan konsumen akan terjadi pula perubahan terhadap keputusan konsumen sebesar 0,404 dan dengan asumsi variabel lain diangap konstan terjadi pengaruh sebesar 0,404 atau $40,4 \%$ terhadap keputusan konsumen membeli. Koefesien regresi faktor promosi memberikan arti bahwa terjadi pengaruh sebesar 0,381 atau $38,1 \%$ terhadap keputusan konsumen membeli. Koefisien regresi faktor layanan purna jual memberikan arti bahwa terjadi pengaruh sebesar 0,229 atau 22,9\% terhadap keputusan konsumen membeli.
Multiple atau koefisien korelasi (R) adalah hubungan antara ketiga variabel bebas yaitu harga, promosi, layanan purna jual, terhadap keputusan konsumen membeli sebesar 0,862 atau 86,2\% artinya hubungan variabel bebas (independen) terhadap variabel terikat (dependen) adalah sangat kuat.

$\mathrm{R}$ Square atau koefisien determinasi $\left(\mathrm{R}^{2}\right)$ adalah melihat pengaruh antara variabel harga, promosi, layanan purna jual, terhadap keputusan konsumen membeli sebesar $74,3 \%$ artinya pengaruh variabel bebas (independen) terhadap variabel terikat (dependen). Sedangkan sisanya $25,7 \%$ adalah pengaruh variabel lain yang tidak diteliti dalam penelitian ini.

\section{Pembuktian Hipotesis}

a. Pembuktian Hipotesis Pertama

Hipotesis pertama yaitu pengaruh harga, promosi, layanan purna jual terhadap keputusan konsumen membeli pada PT. Giovani Palu. Pembuktian hipotesis pertama mengguanakan uji

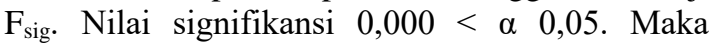
terbukti ketiga variabel bebas yaitu harga, promosi, layanan purna jual, berpengaruh secara serempak terhadap keputusan konsumen membeli pada PT. GIovani Palu.

b. Pembuktian Hipotesis Kedua

Hipotesis kedua yaitu untuk mengetahui apakah variabel harga (X1), secara parsial berpengaruh signifikan terhadap keputusan konsumen membeli pada PT. Giovani Palu. Dari tabel 2 diatas bahwa besarnya probabilitas signifikansi variabel harga (X1) adalah 0,000 < taraf signifikan yang diisyaratkan $\alpha 0,05$. Dengan demikian bahwa secara statistik variabel harga dalam penelitian ini memberikan pengaruh yang signifikan terhadap keputusan konsumen membeli pada PT. Giovani Palu.

c. Pembuktian Hipotesis Ketiga

Hipotesis ketiga yaitu untuk mengetahui apakah variabel promosi (X2), secara parsial berpengaruh signifikan terhadap keputusan konsumen membeli pada PT. Giovani Palu. Dari tabel 2 diatas bahwa besarnya probabilitas signifikansi variabel promosi (X2) adalah 0,000 < taraf signifikan yang diisyaratkan $\alpha 0,05$. Dengan demikian bahwa secara statistik variabel promosi dalam penelitian ini memberikan pengaruh yang signifikan terhadap keputusan konsumen membeli pada PT. Giovani Palu.

d. Pembuktian Hipotesis Keempat 
Hipotesis keempat yaitu untuk mengetahui apakah variable layanan purna jual (X3) secara parsial berpengaruh signifikan terhadap keputusan konsumen membeli Pada PT. Giovani Palu. Dari tabel 2 diatas bahwa besarnya probabilitas signifikansi variabel layanan purna jual (X3) adalah 0,018 < taraf signifikan yang diisyaratkan $\alpha 0,05$. Dengan demikian bahwa secara statistik variabel layanan purna jual dalam penelitian ini memberikan pengaruh yang signifikan terhadap keputusan konsumen membeli pada PT. Giovani Palu.

\section{Pembahasan}

Hasil pembuktian hipotesis dalam penelitian ini pengaruh harga, promosi, dan layanan purna jual terhadap keputusan konsumen membeli motor metic pada PT. Giovani Palu memberikan pembuktian bahwa ketiga variabel independen yaitu harga, promosi, dan layanan purna jual memilki pengaruh secara signifikan terhadap keputusan konsumen membeli.. Dengan demikian dinyatakan bahwa hipotesis mengenai pengaruh harga, promosi, dan layanan purna jual terhadap keputusan konsumen membeli motor metic pada PT. Giovani Palu dapat diterima.

a. Pengaruh Harga, Promosi, Dan Layanan Purna Jual Terhadap Keputusan Konsumen Membeli Motor Metic Pada PT. Giovani Palu

Hasil penelitian membuktikan bahwa penelitian ini seluruh faktor independen berpengaruh positif terhadap keputusan konsumen membeli motor metic pada PT. Giovani Palu. Artinya jika ketiga variabel tersebut diperlukan dalam waktu bersamaan, maka hal tersebut menimbulkan peningkatan keputusan konsumen membeli motor metic pada PT. Giovani Palu.

b. Hubungan Harga Dan Keputusan Konsumen Membeli Motor Metic Pada PT. Giovani Palu.

Harga dapat menunjukkan kualitas merek dari suatu produk, dimana konsumen mempunyai anggapan bahwa harga yang mahal biasanya mempunyai kualitas yang baik. Pada umumnya harga mempunyai pengaruh yang positif dengan kualitas, semakin tinggi harga maka semakin tinggi kualitas. Konsumen mempunyai anggapan adanya hubungan yang positif antara harga dan kualitas suatu produk, maka mereka akan membandingkan antara produk yang satu dengan produk yang lainnya, dan barulah konsumen mengambil keputusan untuk membeli suatu produk. Berdasarkan hasil penelitian di atas menunjukan harga mempengaruhi keputusan konsumen dalam membeli produk. Hal ini karena faktor harga memberikan dorongan atau keinginan konsumen dalam menentukan pilihan atas produk yang diinginkan.

c. Hubungan Promosi Dan Keputusan Konsumen Membeli Motor Metic Pada PT. Giovani Palu

Promosi adalah kegiatan yang dilakukan oleh perusahaan dengan jalan mempengaruhi konsumen secara langsung ataupun tidak langsung untuk meningkatkan omzet penjualan melalui penciptaan pertukaran dalam pemasaran barang. Promosi menjadi faktor yang juga sangat mempengaruhi keputusan konsumen dalam membeli motor metic pada PT. Giovani Palu. Di mana jika promosi penjualan baik maka akan meningkatkan penjualan motor pada perusahaan tersebut.

d. Hubungan Layanan Purna Jual Dan Keputusan Konsumen Membeli Motor Metic Pada PT. Giovani Palu

Layanan purna jual juga dapat mempengaruhi keputusan konsumen membeli Pada dasarnya penjualan atas dasar kedekatan dengan pelanggan dapat menciptakan loyalitas pelanggan atas produk tersebut. Selain itu pemasar juga dapat memperoleh pelanggan baru dari pelayanan yang mereka lakukan. Atas dasar pengertian tersebut dapat diambil kesimpulan bahwa pelayanan purna jual adalah suatu pelayanan yang diberikan oleh perusahaan kepada konsumen setelah pembelian untuk mengurangi ketidakpuasan dengan jalan memberikan garansi, jasa reparasi dan penyediaan suku cadang. Dengan memberikan pelayanan yang baik pada konsumen perusahaan maka akan meningkatkan keinginan konsumen untuk melakukan keputusan pembelian kembali motor pada perusahaan tersebut.

\section{Kesimpulan}

Berdasarkan hasil analisis yang telah dilakukan maka dapat disimpulkan bahwa:

a. Harga, Promosi, dan Layanan Purna Jual secara serempak berpengaruh signifikan terhadap keputusan konsumen membeli motor metic pada PT. Giovani Palu. 
b. Harga berpengaruh signifikan terhadap keputusan konsumen membeli motor metic pada PT. Giovani Palu.

c. Promosi berpengaruh signifikan terhadap keputusan konsumen membeli motor metic pada PT. Giovani Palu.

d. Layanan Purna Jual berpengaruh signifikan terhadap keputusan konsumen membeli motor metic pada PT. Giovani Palu.

\section{Saran-Saran}

Berdasarkan kesimpulan yang di ambil, maka penulis memberikan saran sebagai berikut:

a. Hendaknya menjadikan layanan purna jual sebagai hal prioritas yang harus ditingkatkan agar dapat meningkatkan penjualan motor metik pada PT.Giovani palu.

b. Penulis menyadari dalam penulisan karya tulis ini masih jauh dari kesempurnaan olehnya itu kritik dan saran-saran yang membangun dari dosen pembimbing dan pengguji sangat kami harapkan agar dapat menyempurnakan karya tulis ini.

\section{DAFTAR PUSTAKA}

Augusty Ferdinand. 2006. "Manajemen Pemasaran : Sebuah Pendekatan Strategik“. Program Management Diponegoro University Semarang.

Azis, A. (2019). Pengaruh Fasilitas, Kemampuan Dan Disiplin Kerja Terhadap Kinerja Pegawai Kantor Kecamatan Tinombo Kabupaten Parigi Moutong. Jurnal Ekonomi Trend, 7(2), 30-41.

Badjamal, F. A. (2019). Pengaruh Gaya Hidup Dan Ekuitas Merek Terhadap Keputusan Pembelian Hanphone Merek Samsung Di Kota Palu. Jurnal Ekonomi Trend, 7(2), 1-11.

Ferdinand, (2006). Manajemen Pemasaran, Cetakan Ke-10, Pt. Rajagrafindo Persada, Jakarta

Ghozali, Imam. 2001. "Aplikasi Analisis Multivariate Dengan Program Spss". Badan Penerbit Undip: Semarang

Gujarati. Damodar,1995, “Basic Econometrics”. Mcgraw-Hill International Editions: New York

Handoko, Hani T., 1987. Manajemen Personalia Dan Sumber Daya Manusia. Liberty: Yogyakarta.
Hadi, Sutrisno, 2000, Analisis Butir Untuk Instrumen, Andi Offeset, Yogyakarta

Kotler, Philip, 2001, “Manajemen Pemasaran Analisis, Perencanaan, Implementasi Dan Pengendalian", Jilid 1 - 2, Edisi Indonesia, Salemba Empat, Jakarta.

Kuncoro, Madrajat. 2004. Metode Riset Untuk Bisnis Dan Ekonomi.Jakarta : Pt Gramedia Pustaka.

Marjun, M. (2019). Pengaruh Di Mensi Dimensi Kualitas Layanan Terhadap Kepuasan Pasien Rawat Inap Bpjs Kesehatan Center Rumah Sakit Umum Daerah Anutapura. Jurnal Ekonomi Trend, 7(1), 12-26.

Purwati, (2011) Unsur-Unsur Inti Pemasaran Dan Manajemen Pemasaran Penerbit, Cv. Mandar Maju, Bandung

Raharjani, (2005). Dasar-Dasar Marketing. Penerbit Lpfe.-Ui, Jakarta.

Singgih Santoso, 2000, Buku Latihan Spss Statistik Parametrik, Pt. Elex Media Komputindo Kelompok Gramedia, Jakarta.

Setiadi, 2003, Menjemen Pemasaran Modern, Liberty. Jakarta

Simamora, Bilson. 2003. Membokar Kotak Hitam Konsumen: Jakarta : Pt Gramedia Pustaka

Sugiyono. 2004. Metode Penelitian Bisnis.Bandung : Alfabeta

Sudarsono. 2000. Perilaku Konsumen. Yogyakarta : Amus Yogyakarta.

Tjiptono, Fandy. 2005. Pemasaran Jasa. Jawa Timur : Edisi Pertama. Cetakan Pertama. Bayumedia. 